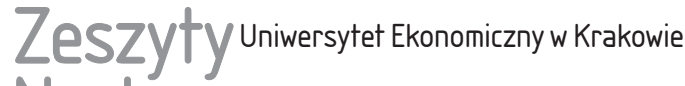 Naukowe
}

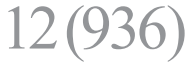

ISSN 1898-6447

Zesz. Nauk. UEK, 2014; 12 (936): 45-61 DOI: 10.15678/ZNUEK.2014.0936.1204

Piotr Lityński

Katedra Gospodarki Regionalnej

Uniwersytet Ekonomiczny w Krakowie

\section{Ekonomiczne konsekwencje przestrzennej decentralizacji i centralizacji miasta na podstawie literatury zagranicznej}

\section{Streszczenie}

Artykuł ma charakter teoretyczny i opiera się na przeglądzie literatury zagranicznej - anglojęzycznej - dotyczącej ekonomicznych kosztów i korzyści przestrzennej centralizacji i decentralizacji miasta. Przedstawiono definicje istoty koncepcji przestrzennej centralizacji miasta, jak i jego decentralizacji. Wskazano metodyczne podstawy oceny ekonomicznej efektywności obu wymienionych koncepcji. Skatalogowano ekonomiczne koszty oraz korzyści wynikające z procesów decentralizacyjnych jak i wdrażania koncepcji centralizacyjnych. Jako przykład określania kosztów i korzyści posłużono się koncepcjami urban sprawl i miasta kompaktowego.

Słowa kluczowe: centralizacja przestrzenna, decentralizacja przestrzenna, urban sprawl, miasto kompaktowe, ekonomiczne koszty, ekonomiczne korzyści.

\section{Wprowadzenie}

W niniejszym artykule skupiono się na dwóch zagadnieniach. Po pierwsze, wśród obserwowanych obecnie procesów przekształceń przestrzeni miast w Polsce i na świecie wymienić można procesy decentralizacyjne, czyli osłabienie roli mieszkaniowej i gospodarczej centrum miasta na rzecz rozwoju 
obszarów podmiejskich. Procesy te są wynikiem decyzji mieszkańców w zakresie osiedlania się, jak i przedsiębiorców w zakresie prowadzenia działalności gospodarczej. Jednocześnie ze względu na kosztochłonność procesów decentralizacyjnych dla podmiotów sektora publicznego zauważalna staje się aktywność władz różnych szczebli w zakresie przeciwdziałania tym procesom. Dzieje się to głównie poprzez wdrażanie polityki przestrzennej bazującej na dogęszczeniu przestrzennej struktury miasta, czyli przestrzennej centralizacji. W krajach wysoko rozwiniętych koncepcje te zaczęto wdrażać w pierwszej połowie lat 90. XX w. Natomiast w Polsce obecnie toczy się dyskusja nad kształtem krajowej polityki miejskiej, która rekomenduje polskim miastom oparcie lokalnej polityki przestrzennej na założeniach koncepcji miasta zwartego, czyli jednej z koncepcji centralizacji przestrzennej.

Po drugie, zarówno przestrzenne procesy decentralizacyjne, jak i koncepcje centralizacji miasta wywołują wiele konsekwencji społecznych, środowiskowych, przestrzennych oraz ekonomicznych. W polskiej literaturze przedmiotu obecne są treści traktujące głównie o konsekwencjach społecznych, środowiskowych i przestrzennych, natomiast wymiar ekonomiczny nie jest wystarczająco rozpoznany. Ponadto te z opracowań, które dotyczą aspektów ekonomicznych, ujmowane są na ogół jako koszty finansowe wymienionych uprzednio trzech grup konsekwencji. W znikomym natomiast stopniu formułuje się wnioski opierające się na badaniach, u podstaw których leży dorobek teorii ekonomii.

W świetle wymienionych przesłanek za cel główny opracowania przyjęto identyfikację konsekwencji ekonomicznych wynikających z przestrzennych procesów decentralizacyjnych, jak i wdrażania koncepcji centralizacyjnych. Uważa się również, że cel główny osiągnięty zostanie w drodze realizacji dwóch celów szczegółowych: 1) określenie istoty przestrzennych procesów decentralizacyjnych oraz centralizacyjnych, jak i teoretycznych podstaw ekonomicznej oceny tytułowych zagadnień; 2) identyfikacja i wyjaśnienie konsekwencji ekonomicznych omawianych procesów, przyjmując, że konsekwencje ekonomiczne rozumiane będą jako koszty i korzyści dla gospodarki przedstawiane w kategoriach ekonomicznych.

Procesy decentralizacyjne w Polsce obserwowane są od kilkunastu lat, podczas gdy w krajach wysoko rozwiniętych od kilkudziesięciu, dlatego jako metodę osiągnięcia stawianych w opracowaniu celów przyjęto przegląd zagranicznego dorobku empirycznego i teoretycznego. Dokonano zatem przeglądu literatury anglojęzycznej wynikającej z doświadczeń amerykańskich, europejskich i azjatyckich. 


\section{Istota zjawiska przestrzennej decentralizacji i centralizacji miasta}

Decentralizacja przestrzenna istotnie wiąże się ze zjawiskiem rozproszenia zabudowy lub inaczej - ,rozlewania się" miast (urban sprawl), które opisywane jest jako proces decentralizacji populacji i zatrudnienia w mieście na rzecz gmin podmiejskich, a jednocześnie w niewielkim stopniu kontrolowane przez regionalną politykę przestrzenną [Perrsky i Wiewel 2012, s. 152]. Wśród przejawów decentralizacji przestrzennej wymienić można: rozproszenie zabudowy, niskie wskaźnikami gęstości zamieszkania, uzależnienie społeczeństwa i gospodarki od zmechanizowanego transportu (samochodowego, kolejowego).

Zjawisko decentralizacji przestrzennej miast wiąże się głównie z luźną formą zabudowy mieszkaniowej zarówno na skraju miast, jak i w sferze podmiejskiej. Zabudowa ta jest niska, parterowa lub jednopiętrowa, o wyraźnym braku centrum i charakteryzuje się brakiem ciągłości przestrzennej. Często brak ciągłości zabudowy określa się terminem, „żabiego skoku” (leapfrog), co oznacza, że osiedla mieszkaniowe powstają wewnątrz terenów rolniczych i tworzą mozaikę (patchwork) nieprzypominającą zwartego miasta - tereny zurbanizowane występują na przemian z rolniczymi lub leśnymi [Ewing 1997, s. 107-125].

Zjawisko decentralizacji przyczyniło się do poszukiwania zrównoważonej formy przestrzennej, która pod koniec lat $80 \mathrm{XX}$ w. wywołała dyskusję zarówno w literaturze naukowej, jak i w sferze polityki publicznej [Breheny 1992, s. 4; Haughton i Hunter 1994, s. 7; Jenks, Burton i Williams 1996, s. 3; Future Forms... 2005, s. 5]. W konsekwencji, w odpowiedzi na zagrożenia związane z procesami decentralizacyjnymi zaczęto formułować kontrkoncepcje nawiązujące do dogęszczania struktury przestrzennej miasta - koncepcje centralizacji przestrzennej miasta. W Europie istotną rolę odegrał dokument Green Paper on the Urban Environment opublikowany w 1990 r. przez Komisję Europejską, który wprowadził pojęcie miasta kompaktowego (Compact City) jako archetyp zrównoważonej formy europejskich miast. Pojawienie się koncepcji miasta kompaktowego wywołało dyskusję naukową, w której rozważano zalety wprowadzania wysokich wskaźników zabudowy [Elkin, McLaren i Hillman 1991, s. 16]. W nurcie koncepcji związanych z centralizacją przestrzenną miasta - oprócz koncepcji miasta kompaktowego - istnieją również inne, które nawiązują do jej założeń. Są to: nowy urbanizm [Porter 2002, s. 1-5], rozwój oparty na transporcie [Calthorpe 1993, s. 56], inteligentny rozwój [Porter 2002, s. 1-5; O’Neil 2000, s. 2].

Centralizacja przestrzenna miasta wiąże się z wysokimi wskaźnikami zabudowy i zamieszkania w mieście, zróżnicowanym użyciem przestrzeni, gdzie rozwój inicjowany jest $\mathrm{w}$ ramach granic miasta, a nie poza peryferiami [Burton 2000, s. 1969-2007; Breheny 1992, s. 8]. Ponadto dla centralizacji 
przestrzennej miasta ważny jest wydajny publiczny system transportowy, jak i wymiar przestrzeni zachęcający do przemieszczania się pieszo lub rowerem. Jednakże zdarzało się, że centralizacja była nadinterpretowana jako zbyt wysokie wskaźniki zabudowy prowadzące do przeludnienia, braku przestrzeni otwartych lub zielonych oraz wzrostu cen mieszkań [Neuman 2005, s. 11; Breheny 1996, s. 13-35; Gordon i Richardson 1997, s. 96- 106]. Makroekonomiczne spojrzenie na empiryczną i merytoryczną problematykę centralizacji przestrzennej miast jest również aktualne, czego wyrazem jest publikacja OECD [Compact City Policies... 2012, s. 29], w której wskazuje się zalety i potrzeby wdrażania polityki przestrzennej opartej na założeniach koncepcji miasta kompaktowego.

\section{Teoretyczne podstawy ekonomicznej oceny efektywności decentralizacji i centralizacji przestrzennej miasta}

Punktem wyjścia dla ekonomicznej oceny efektywności przestrzennych procesów decentralizacyjnych, jak i centralizacyjnych miasta będzie definicja urban sprawl używana przez ekonomistów w literaturze zagranicznej. W tym ujęciu urban sprawl określany jest jako nadmierna decentralizacja obszaru miejskiego nakładająca większe koszty krańcowe netto na wszystkie podmioty w obszarze, niż gdyby rozwój pozostał bardziej scentralizowany [Gordon i Richardson 1996, s. 1727-1743; Mills 1999, s. 1-7; Brueckner 2000, s. 16-171]. Wspomniane koszty krańcowe netto dotyczą [Wassmer 2002, s. 4]:

- dodatkowych kosztów gospodarstw domowych powstałych na skutek decyzji lokalizacji w obszarze suburbiów podejmowanych przez gospodarstwa domowe i prywatne podmioty gospodarcze,

- dodatkowych kosztów podmiotów sektora publicznego będących rezultatem decyzji lokalizacji gospodarstw domowych i prywatnych jednostek gospodarczych.

W perspektywie ekonomicznej, zastosowanie kosztów krańcowych netto stosuje się również do określenia korzyści netto prywatnych oraz społecznych wynikających z decyzji lokalizacji w suburbiach. Takie podejście ujawnia potrzebę oceniania ekonomicznych kosztów i korzyści ponoszonych przez wszystkie podmioty gospodarki, tj. w podziale na podmioty sfery realnej i regulacji, w celu wykazania społecznej i ekonomicznej efektywności. Potrzeba kompleksowego oceniania konsekwencji dla podmiotów sfery realnej i regulacji może okazać się problematyczna, gdyż część kosztów i korzyści nie daje się ująć w kategoriach monetarnych. Dlatego w ekonomii rozwinięte zostały takie metody, jak „chęć do zapłaty”, aby podjąć próbę oceny analizowanego zjawiska. Uwzględniając trudności tej metody, ekonomiści podejmują próbę zastoso- 
wania jej przy wykorzystaniu koncepcji kosztów krańcowych netto w ocenie procesów decentralizacyjnych. Wskazuje się, że decentralizacja przestrzenna jest niekorzystna, gdy koszty krańcowe netto (prywatne i społeczne) przewyższają korzyści krańcowe netto (prywatne i społeczne). Jest to jednak metoda, która nie ocenia jako korzystne lub niekorzystne indywidualne decyzje lokalizacji.

Próba zestawienia w pkt 4 dorobku literatury zagranicznej w zakresie identyfikacji ekonomicznych kosztów i korzyści dotyczących przestrzennych procesów decentralizacyjnych (na przykładzie urban sprawl) oraz centralizacji przestrzennej miasta (na przykładzie koncepcji miasta kompaktowego) może okazać się przydatna szczególnie w empirycznym określaniu wspomnianych kosztów i korzyści krańcowych netto.

\section{Konsekwencje procesów decentralizacyjnych}

\subsection{Koszty decentralizacji przestrzennej}

Problematyka związana z kosztami decentralizacji przestrzennej miast obecna jest w literaturze zagranicznej od pierwszej połowy XX w. Do głównych kosztów o charakterze ekonomicznym zalicza się [Mumford 1961, McHarg 1969, Costs of Sprawl... 1974, Jackson 1985, Downs 1994, Beyond Sprawl... 1995, Fulton i in. 2002]: zwiększenie wydatków publicznych na obsługę infrastruktury i usług publicznych, nieefektywność zużycia energii, negatywny wpływ na budżet gospodarstw domowych; negatywny rynkowo wpływ na centrum miasta.

\section{Zwiększenie wydatków publicznych na obstugę infrastruktury i ustug publicznych}

„Rozlewanie się” miasta generuje istotne koszty ponoszone przez podmioty sektora publicznego, które związane są przede wszystkim z dwoma czynnikami. Pierwszy dotyczy zwiększonego popytu na dobra i usługi świadczone przez sektor publiczny ze względu na zwiększenie liczby mieszkańców przedmieść, a drugi potęgowany jest na skutek niskich wskaźników zabudowy w obszarach zdecentralizowanych i istotnego zwiększenia zasięgu obsługi mieszkańców przez sektor publiczny. Zwiększone koszty ponoszone przez sektor publiczny dotyczą głównie potrzeby rozbudowy infrastruktury drogowej, budowy nowej infrastruktury edukacyjnej, sieci wodno-kanalizacyjnych, sieci energetycznej, stacji straży pożarnej, policji, placówek zdrowotnych, infrastruktury komunikacji miejskiej lub podmiejskiej [Bhatta 2010, s. 17; Brueckner et al. 2000, s. 16-171]. Podobny problem powstaje $\mathrm{w}$ przypadku tworzenia i utrzymania publicznych środków masowego transportu [Litman 2004, s. 12]. Jednocześnie zwiększone koszty związane z obsługą infrastruktury przedmiejskiej nie są uważane za problematyczne w ramach określonego osiedla przedmiejskiego, ale raczej są 
pochodną stopnia zagęszczenia zabudowy w tych osiedlach. Podobnie stanowisko zauważalne jest w temacie kosztów świadczenia usług publicznych [Heimlich i Anderson 2001].

Nieefektywność zużycia energii

Nieefektywność zużycia energii wiąże się głównie z nadmiernym zużyciem paliwa przez samochody oraz zwiększonymi kosztami przesyłu energii elektrycznej. Należy zwrócić uwagę, że większa gęstość zamieszkania oznacza mniejsze odległości, ale spowodować może zwiększenie zatłoczenia. Wskazuje się, że efekty większej gęstości zamieszkania przewyższają koszty związane z nadmiernym zatłoczeniem obszaru [Newman i Kenworthy 1989]. Pomimo że zużycie paliwa przez samochody w obszarze miejskim jest wyższe niż na przedmieściach, ogólne zużycie paliwa per capita w mieście jest znacznie mniejsze, ze względu na rzadsze wykorzystanie samochodów. Zjawisko decentralizacji przestrzennej powoduje zwiększenie odległości do centrum, a w konsekwencji większe zużycie paliwa, równocześnie generując nadmierne zatłoczenie. Zwiększona liczba samochodów na drogach o dłuższych odcinkach jest powodem tworzenia się korków i zwiększonego zużycia paliwa.

Co się tyczy elektryczności, w literaturze podkreśla się zwiększenie kosztów związanych z koniecznością rozszerzania zasięgu linii elektrycznych oraz utrzymania sieci przesyłu energii. Podobne zależności wskazuje się w zakresie systemu dostarczania wody. Równolegle $\mathrm{z}$ omawianymi kosztami ważną rolę odgrywają koszty związane z utratą tych zasobów w procesie dostarczania do konsumenta. Im większa odległość od generatora zasobu, tym więcej energii jest utraconej w procesie dostarczania [Bhatta 2010, s. 17].

Negatywny wpływ rozproszenia zabudowy na budżet gospodarstw domowych

Negatywny wpływ rozproszenia zabudowy na budżet gospodarstw domowych wiąże się głównie ze zwiększeniem zakresu użytkowania samochodów. Ekonomiczne konsekwencje zjawiska przejawiają się w zwiększonej liczbie pojazdów przypadających na jedno gospodarstwo domowe, co prowadziło do zwiększenia wydatków na: paliwo, ubezpieczenie, utrzymanie pojazdów, okresowy zakup nowych pojazdów [Litman 2004, s. 30].

Negatywny rynkowo wplyw na centrum miasta

Decentralizacja miasta przejawia się odpływem mieszkańców z centrum miasta na przedmieścia. Proces taki może wywołać obniżenie zagregowanego popytu oraz obniżenie wydajności pracy w sektorze usługowym ze względu na zmęczenie długimi dojazdami do pracy. Jednocześnie odpływ mieszkańców $\mathrm{z}$ centrów prowadzi do obniżenia koncentracji popytu bazującego na wydatkach 
mieszkańców, czego skutki będą obserwowane po stronie podażowej np. poprzez redukcję rozłożenia ważnych usług.

\subsection{Korzyści decentralizacji przestrzennej}

Konkluzje co do nadmiernej decentralizacji miast zauważalne są również w anglosaskiej literaturze ekonomicznej, której problematyka ogniskuje się wokół badań kosztów zatłoczenia komunikacyjnego, na podstawie modelu miasta monocentrycznego [Anas 2012, s. 123].

Jednak coraz częściej pojawiają się wyniki rozważań naukowych wskazujące, że rozproszenie miasta oraz rozwój jego granic może okazać się potencjalnie korzystne pod względem ekonomicznym. Konkluzje takie dostarczane są przede wszystkim przez badania, u podstaw których leżą założenia miasta policentrycznego. Wskazuje się w tym przypadku, że wraz z rozwojem zawodów mobilnych, prac zawodowych w więcej niż jednym mieście, rozwojem i wzrostem znaczenia Internetu i innych środków telekomunikacyjnych w gospodarce, pojawienie się rozproszenia zabudowy miasta oceniane może być pozytywnie. Przykłady konkluzji takich dostarczają symulacje w ramach tzw. „chicagowskiego komputerowego modelu równowagi ogólnej" z endogeniczną siecią ruchu drogowego. Symulacje w ramach tego modelu wskazują, że we wzajemnie powiązanych przedmiejskich obszarach mieszkalnych i miejsc pracy, średni czas przemieszczania się utrzymuje się stałym poziomie nawet wówczas, gdy: miasto „rozlewa się”, wzrasta odległość „,dom-praca”, a liczba mieszkańców oraz PKB rośnie [Anas 2012, s. 124]. Równolegle do wyników symulacji modelu narodowe (amerykańskie) dane z okresu 1990-2000 dotyczące przemieszczania się ludności wskazują, że w miastach, które powiększyły się dwukrotnie, średnio tylko o 10\% wydłużył się przejazd z miejsca zamieszkania do miejsca docelowego (np. pracy).

Część ekonomistów negatywnie ocenia zjawisko decentralizacji przestrzennej miast, interpretując konsekwencje tego zjawiska jako złą alokację zasobów. Wyniki takie dostarczane są przez badania opierające się na modelu miasta monocentrycznego. W modelach tych wszyscy mieszkańcy dojeżdżają do miasta centralnego - CBD (Central Bussines District) - do pracy, co wiąże się z przeludnieniem i „korkami”. Przywiązanie ekonomistów do podejścia badawczego bazującego na wspomnianym modelu było na tyle trwałe, że rezultaty tych badań zaczęły być implementowane do praktyki planistycznej. Jednakże współczesne badania opierające się na modelu policentrycznym z rozprzestrzenionymi miejscami pracy wskazują, że optymalną formę urbanistyczną miasta można otrzymać, rozprzestrzeniając miasto. W wielu okolicznościach decentralizacja miasta może okazać się istotna w odniesieniu do: utrzymania kosztów komunikacji na stabilnym i niskim poziomie, ograniczenia przeludnienia, ekonomicznej efektywności gospodarki. Ponadto decentralizacja miasta może okazać się 
korzystna, mając na uwadze możliwość wyprowadzenia miejsc pracy z przeludnionego i kosztownego CBD, co ma miejsce w praktyce. Wnioski takie sformułowano na podstawie symulacji przeprowadzonej w USA [Anas 2012, s. 123].

Inne badania bazujące na policentrycznym modelu miasta [Anas i Rhee 2006, s. 510-541] wykazały, że „rozlanie” miasta mierzone kosztami dojazdu do pracy, średnim dziennym czasem dojazdu do pracy oraz gęstością zamieszkania i miejsc pracy, ocenić można jako korzystniejszy niż centralizację. W tych badaniach wykazano, że w sytuacji gdy miasto transformowane jest z układu policentrycznego do monocentrycznego (np. implementowanie koncepcji miasta kompaktowego) czas dojazdu do pracy zwiększy się o 9,1\%.

Należy zwrócić uwagę, że redukcja kosztów transportu, rozwój technologii komunikacyjnych oraz Internetu, wzrost znaczenia powiązań pomiędzy miastami osłabiły korzyści aglomeracyjne. Jednocześnie jest mało prawdopodobne odwrócenie tego trendu, zatem korzyści aglomeracyjne nie będą prawdopodobnie ponownie pełnić tak istotnej roli, by przywrócić istotność monocentrycznych analiz.

\section{Konsekwencje wdrażania koncepcji opartych na założeniach centralizacji przestrzennej miasta}

\subsection{Korzyści centralizacji przestrzennej}

Wśród korzyści wdrażania koncepcji opierających się na centralizacji przestrzennej miasta wymienia się: sprawniejsze dostarczanie usług publicznych, lepszy dostęp do miejsc pracy, sprawniejsze wykorzystanie energii elektrycznej dostarczanej do określonego obszaru/dzielnicy, krótsze dystanse przejazdów w mieście, wyższą wydajność pracy pracowników powodowaną spędzaniem krótszego czasu dojazdu „do i z” miejsca pracy [Compact City Policies... 2012, s. 57]. Z perspektywy ekonomicznej jednym z istotniejszych skutków realizacji koncepcji jest osiągnięcie tzw. gospodarczego efektu zagęszczenia stymulującego wzrost zagregowanego popytu i podaży w mieście.

\section{Redukcja kosztów związanych z miejska infrastruktura}

Chociaż nie ma zbyt wielu opracowań na temat ekonomicznych konsekwencji wdrażania koncepcji centralizacyjnych, to szeroko omawiany w literaturze fachowej jest ich wpływ na obniżenie kosztów związanych z miejską infrastrukturą. Korzyści ekonomiczne redukcji kosztów obsługi infrastruktury są szczególnie istotne dla sektora publicznego jako opcja uzupełnienia luki czy niedoborów infrastrukturalnych. Wdrażanie polityki opartej na założeniach koncepcji centralizacyjnych może podwyższyć wydajność inwestycji infrastrukturalnych 
oraz zredukować koszty jej utrzymania, w szczególności liniowych systemów transportowych, dostarczania energii i wody, odprowadzania ścieków.

Efekty ekonomiczne związane z redukcją kosztów funkcjonowania miasta przestrzennie scentralizowanego mogą okazać się znaczące. Jako przykład można wskazać badania przeprowadzone w Stanach Zjednoczonych w 2002 r. [Costs of Sprawl... 2002, Towards a Green Economy... 2011] oceniające wpływ „rozlewania się" miast na koszty zasobów poprzez ocenę kosztów infrastruktury wodno-kanalizacyjnej w obszarach kontrolowanego i niekontrolowanego wzrostu. Według tych kalkulacji możliwe byłoby zaoszczędzenie 12,6 mld USD poprzez ograniczenie „rozlewania się” miast; 110 mld USD oszczędności w zakresie infrastruktury drogowej, a w odniesieniu do usług publicznych redukcja kosztów oscylowała w granicach 4 mld USD. Podobnych wniosków dostarczają wyniki badań przeprowadzonych w Japonii [A Study on Regional Infrastructure... 2009].

\section{Wzrost wydajności pracy}

Potencjalną korzyścią może być to, że na skutek wdrażania koncepcji miasta kompaktowego może dojść do wzrostu wydajności pracy. Badania przeprowadzone w 2011 r. wskazują, że podwojenie gęstości zamieszkania (gęstości zasobów siły roboczej) określonego obszaru zurbanizowanego może przyczynić się do wzrostu wydajności pracy o 6\%. Ponadto wskazuje się również, że gęstość aktywności gospodarczej jest istotna w wyjaśnieniu zmienności wydajności pracy na poziomie regionalnym: średnia wydajność pracy rośnie o $6 \%$, gdy gęstość zasobów siły roboczej jest podwojona w skali krajowej. Podobnych konkluzji dostarczają wyniki badań przeprowadzonych przez R. Cervero [2001, s. 1651-1671].

Ponadto niższe koszty transportu w mieście mogą usprawnić funkcjonowanie rynku pracy. Zakres interakcji podmiotów gospodarczych i gospodarstw domowych jest ograniczany przez koszty transportu, a wzrost liczby pracodawców i pracobiorców poszukujących lepszych relacji zawodowych podwyższa oczekiwaną jakość tych relacji. Jednocześnie odnalezienie tych relacji ma pozytywny efekt w wydajności pracy. Ponadto presja konkurencyjności z powodu koncentracji geograficznej przyczynia się do znacznego wzrostu innowacyjności [Jones $\mathrm{i}$ in. 2010].

W ramach koncepcji miasta kompaktowego podkreśla się, że skrócenie dystansu dojazdu do miejsca pracy redukuje czas podróży w wyniku czego wzrasta wydajność pracy. Przykładowo, w 1999 r. przeprowadzono badania [Prud'homme i Lee 1999, s. 1849-1858] wykazujące, że ograniczenie decentralizacji miasta oraz zwiększenie prędkości transportu o $10 \%$ prowadzi do wzrostu wydajności pracy o $2,9 \%$. 


\section{Gospodarczy efekt zagęszczenia}

W literaturze przedmiotu odnaleźć można studia argumentujące, że centralizacja struktury miasta generuje tzw. gospodarczy efekt zagęszczenia (economies of density) [Morikawa 2011, s. 179-192; Jones et al. 2010]. Odpowiednia gęstość zamieszkania kreuje stabilny popyt szczególnie na usługi oraz może zwiększyć wydajność pracy w sektorze usługowym. Mechanizm efektów dogęszczenia struktury miasta wpływający na gospodarkę poprzez stronę popytową jest inny od zróżnicowania i dyfuzji wiedzy bazujący na stronie podażowej. Wysoka gęstość zamieszkania prowadzi do dużej koncentracji popytu opierającego się na wydatkach mieszkańców, co może zredukować przestrzenne rozłożenie ważnych społecznych i prywatnych usług. Oznacza to, że wysoka gęstość zamieszkania stymuluje wydajność pracy w sektorze usług. Wnioski te znajdują uzasadnienie w badaniach przeprowadzonych w Japonii [Morikawa 2011, s. 179-192], gdzie wykazano, że wydajność pracy w wybranych gałęziach sektora usług wzrosła od $7 \%$ do $15 \%$, po tym jak gęstość zamieszkania w miastach podwoiła się. Wyniki tych badań potwierdzają wcześniej przeprowadzone analizy w przedmiocie [Tabuchi 1986, s. 211-228; Ciccone i Hall 1996, s. 54-70; Lucas i Rossi-Hansberg 2002, s. $1445-1476$ ].

\subsection{Koszty centralizacji przestrzennej}

W pierwszej połowie lat 90. XX w., gdy sformułowano koncepcję miasta kompaktowego, wierzono $\mathrm{w}$ zdolność tej koncepcji do zapewnienia równowagi w mieście, w tym równowagi gospodarczej. Podejście to było tak dominujące, że nie rozważano możliwości niepowodzeń w realizacji tej koncepcji [Guy i Marvin 2000, s. 9]. Jednakże kiedy zaczęto wdrażać politykę przestrzenną opartą na założeniach koncepcji miasta kompaktowego, badania ex post tej polityki zaczęły dostarczać wniosków, że pierwotnie przewidywane korzyści nie zaistniały. Uwagi krytyczne pojawiały się m.in. w zakresie nieosiągnięcia celów i efektów polityki w odniesieniu do realnych potrzeb gospodarczych miast, w tym popytu [Thomas i Cousins 2000, s. 53]. Ponadto udowodniono znaczącą dysproporcję pomiędzy wizją idealnego, tętniącego życiem miasta a rzeczywistością zatłoczonego miasta. Inaczej ujmując, miasto stało się miejscem, z którego wiele osób pragnęło przenieść się na przedmieścia lub wieś, co w efekcie przyczyniało się do decentralizacji miasta [Williams 1999, s. 167-178].

Na podstawie analizy literatury ocena koncepcji miasta kompaktowego w odniesieniu do zrównoważenia miasta wskazuje, że relacja pomiędzy kompaktowością a zrównoważeniem może być: negatywnie skorelowana, słabo skorelowana lub skorelowana w ograniczonym zakresie [Neuman 2005, s. 13]. Inne natomiast badania [Breheny 1997, s. 209-217; Jenks 2000, s. 35] dostarczają 
wniosków, że nie można wprost wykazać sprzężenia pomiędzy wyższą gęstością zamieszkania a redukcją użytkowania samochodów. Wskazuje się, że rodzaj podróży samochodem wpływa na intensyfikację użytkowania gruntów. Podczas gdy krótkie podróże do lokalnych aktywności mogą ulec obniżeniu, to odległość od profesjonalnego miejsca pracy, specjalistycznych sklepów, miejsc spędzania czasu wolnego może być uzależniona od gęstości tkanki miejskiej. Wzrost liczby posiadaczy samochodów, weekendowe oraz biznesowe podróże, podobnie jak zróżnicowane i zmieniające się wzorce życiowe doprowadziły do problemów w określaniu popytu na podróż środkami transportu masowego.

Z kolei z badań przeprowadzonych na krajowych danych w Holandii, gdzie wdraża się koncepcję miasta kompaktowego, wynika, że średnie zużycie energii na transport per capita w różnych obszarach wahało się tylko o 5\% [Bouwman 2000, s. 235]. Oznacza to, że ograniczenie energii będące efektem wrażania koncepcji miasta kompaktowego nie zostało udowodnione.

Badania przeprowadzone w Wielkiej Brytanii w zakresie wpływu form urbanistycznych na transport dostarczają wniosków [Hall 2001, s. 102], że wyniki badań wielu różnych autorów nie można uznać za spójne i mogą być mylące. Autor analizuje i porównuje wiele badań, konkludując, że wyniki są dwuznaczne. W dużej części tych badań podejmowano analizy tylko jednego z parametrów podróżowania (dystans, czas, częstotliwość) zamiast ujęcia bardziej kompleksowego. Z drugiej strony, inne badania wykazywały brak istotnych statystycznie powiązań pomiędzy częstotliwością podróżowania a gęstością zamieszkania [Ewing 1997, s. 107-126; Hall 2001, s. 110]. Z kolei odrębne badania wskazują słabą korelację pomiędzy gęstością zamieszkania a zużyciem energii do transportu [Breheny, Gordon i Archer 1998, s. 15]. Jednocześnie w wymienianych badaniach utrzymuje się, że podróżowanie jest mocniej skorelowane z ceną paliw i dochodów mieszkańców niż gęstością zamieszkania. Wnioski z badań pozwalają odrzucić również tezę, że wzrost gęstości zabudowy koniecznie zredukuje podróżowanie w miastach.

Wśród kosztów wdrażania koncepcji nawiązujących do podstaw centralizacji przestrzennej miasta odnaleźć można również inne wskazujące, że w wyniku dogęszczania struktury tkanki miejskiej występują ograniczenia w podaży gruntów, co prowadzi do: niedoborów mieszkaniowych, przestrzeni biurowej, wysokich czynszów, wysokich cen nieruchomości [Cheshire i Sheppard 2002, s. 242-269]. W wyniku czego miasta z nieadekwatnym rynkiem nieruchomości stają się bardzo drogim miejscem do prowadzenia działalności gospodarczej, wysokimi cenami mieszkań i ograniczoną mobilnością siły roboczej [Baker 2004]. Ponadto rozwój przestrzeni w istniejącym obszarze zurbanizowanym może być bardziej kosztowny z powodu odnowy znajdującej się tam zdegradowanej infrastruktury, co jest istotnym utrudnieniem dla prywatnych inwestycji 
[Troy 1992, s. 216-233]. Wskazane efekty negatywne wpływają na gospodarcze możliwości rozwojowe miasta oraz jego bieżącą aktywność gospodarczą, co może negatywnie oddziaływać na konkurencyjność miasta [Compact City Policies... 2012, s. 71].

Innym kosztem ekonomicznym wdrażania omawianych koncepcji może być zubożenie gospodarcze obszarów pogranicza miasta. Podczas gdy koncepcja miast scentralizowanych przestrzennie może wzmocnić wzrost gospodarczy metropolii jako całości poprzez lepszy dostęp do zróżnicowanych usług i miejsc pracy, to mieszkańcy z obszarów granic metropolii mogą utracić możliwości rozwoju gospodarczego [Compact City Policies... 2012, s. 72].

\section{Wnioski}

Przedstawione rozważania pozwalają na sformułowanie wniosków, które ująć można następująco:

1) decentralizacja przestrzenna miasta na ogół jest wartościowana negatywnie. Jednocześnie owo wartościowanie formułowane jest głównie z perspektywy kosztów ponoszonych przez jednostki samorządu terytorialnego. Dlatego tworzone są alternatywne koncepcje urbanistyczne ukierunkowane na dogęszczanie struktury przestrzennej miasta, $\mathrm{tj}$. centralizację przestrzenną miasta. Koncepcje te w założeniu mają wychodzić naprzeciw problemom gospodarczym generowanym przez zjawisko decentralizacji;

2) korzyści ekonomiczne centralizacji przestrzennej miasta są szczególnie istotne dla podmiotów sektora publicznego ze względów na ograniczenia finansowe samorządów terytorialnych. Natomiast procesy przestrzenne decentralizacyjne wymagają relatywnie wysokich nakładów infrastrukturalnych. Wdrażanie polityki opartej na założeniach koncepcji centralizacyjnych mogą podwyższyć wydajność inwestycji infrastrukturalnych oraz zredukować koszty jej utrzymania;

3) wdrażanie polityki przestrzennej opartej na założeniach centralizacji przestrzennej miasta dostarcza wniosków, że pierwotnie przewidywane korzyści nie zaistniały. Ponadto udowodniono znaczącą dysproporcję pomiędzy wizją idealnego, tętniącego życiem miasta a rzeczywistością zatłoczonego miasta. Inaczej ujmując, miasto stało się miejscem, z którego wiele osób pragnęło przenieść się na przedmieścia lub wieś, co w efekcie przyczyniało się do przestrzennej decentralizacji miasta;

4) utożsamianie decentralizacji przestrzennej z ujemnym bilansem ekonomicznych kosztów i korzyści, które bazuje wyłącznie na optyce podmiotów sektora publicznego, wydaje się podejściem niepełnym. Analiza taka nawiązy- 
Tabela 1. Ekonomiczne konsekwencje dla gospodarki miasta związane z przestrzenną decentralizacją i centralizacją

\begin{tabular}{|c|c|c|}
\hline \multirow{2}{*}{ Konsekwencje } & \multicolumn{2}{|c|}{ Podmioty gospodarki } \\
\hline & podmioty sfery realnej & podmioty sfery regulacji \\
\hline $\begin{array}{l}\text { Koszty } \\
\text { decentralizacji } \\
\text { przestrzennej }\end{array}$ & $\begin{array}{l}\text { - nieefektywność zużycia energii } \\
\text { - negatywny wpływ na budżet gospo- } \\
\text { darstw domowych } \\
\text { - negatywny wpływ na centrum } \\
\text { miasta }\end{array}$ & $\begin{array}{l}\text { - zwiększenie wydatków publicznych } \\
\text { na obsługę infrastruktury i usług } \\
\text { publicznych }\end{array}$ \\
\hline $\begin{array}{l}\text { Korzyści } \\
\text { decentralizacji } \\
\text { przestrzennej }\end{array}$ & $\begin{array}{l}\text { - wzrost gospodarczy } \\
\text { - efektywność gospodarki } \\
\text { - wzrost wydajności pracy } \\
\text { - obniżenie kosztów funkcjonowania } \\
\text { podmiotów gospodarczych } \\
\text { - wzrost populacji, wzrost zagregowa- } \\
\text { nego popytu i podaży } \\
\text { - wzrost dochodów budżetów gospo- } \\
\text { darstw domowych } \\
\text { - utrzymanie kosztów komunikacji na } \\
\text { niskim stabilnym poziomie } \\
\text { - ograniczenie przeludnienia i odciąże- } \\
\text { nie kosztownego centrum miasta }\end{array}$ & - efektywność gospodarki \\
\hline $\begin{array}{l}\text { Koszty } \\
\text { dogęszczania } \\
\text { struktury } \\
\text { miasta }\end{array}$ & $\begin{array}{l}\text { - zakładane pierwotnie korzyści nie } \\
\text { zostały ostatecznie osiągnięte } \\
\text { - rynek, w sensie ekonomicznym, nie } \\
\text { poddaje się ograniczaniu przestrzen- } \\
\text { nemu } \\
\text { - wzrost cen nieruchomości, wysokie } \\
\text { czynsze } \\
\text { - niedobory mieszkaniowe, przestrzeni } \\
\text { gospodarczych } \\
\text { - obniżenie konkurencyjności gospo- } \\
\text { darki miasta } \\
\text { - zubożenie gospodarcze obszarów } \\
\text { pogranicza miasta }\end{array}$ & $\begin{array}{l}\text { - zakładane pierwotnie korzyści nie } \\
\text { zostały ostatecznie osiągnięte } \\
\text { - zdegradowana przestrzeń wyma- } \\
\text { gająca dodatkowych nakładów } \\
\text { inwestycyjnych } \\
\text { - zubożenie obszarów pogranicza } \\
\text { miasta, wymagających później- } \\
\text { szych nakładów finansowych }\end{array}$ \\
\hline $\begin{array}{l}\text { Korzyści } \\
\text { dogęszczania } \\
\text { struktury } \\
\text { miasta }\end{array}$ & $\begin{array}{l}\text { - gospodarczy efekt zagęszczenia sty- } \\
\text { mulującego wzrost zagregowanego } \\
\text { popytu i podaży } \\
\text { - wzrost gospodarczy centrum miasta } \\
\text { - wyższa wydajność pracy } \\
\text { - efektywniejsze wykorzystanie zaso- } \\
\text { bów, szczególnie ziemi } \\
\text { - obniżenie kosztów transportu } \\
\text { i energii } \\
\text { - dostępność miejsc pracy, krótsze } \\
\text { dystanse przejazdów w mieście }\end{array}$ & $\begin{array}{l}\text { - redukcja kosztów związanych } \\
\text { z miejską infrastrukturą, usług } \\
\text { publicznych }\end{array}$ \\
\hline
\end{tabular}

Źródło: opracowanie własne. 
wałaby bowiem głównie do wąskiego wycinka gospodarki, tj. podmiotów sfery regulacji. Natomiast nie mniej istotna jest analiza kosztów i korzyści ponoszonych przez podmioty sfery realnej gospodarki, tj. podmiotów gospodarczych, gospodarstw domowych, konsumentów;

5) eksponowanie (na ogół) przewagi kosztów z decentralizacji przestrzennej miasta wiąże się również z rozpowszechnionymi wynikami badań bazującymi na modelu miasta monocentrycznego. $Z$ drugiej strony, pojawiają się wyniki rozważań naukowych wskazujących, że decentralizacja przestrzenna miasta może okazać się potencjalnie korzystne z ekonomicznego punktu widzenia. Konkluzje takie dostarczane są przez badania, u podstaw których leżą założenia miasta policentrycznego;

6) teoria oceny ekonomicznej efektywności przestrzennych procesów decentralizacyjnych i centralizacyjnych miasta bazuje na podstawach kosztów krańcowych netto dotyczących wszystkich podmiotów w analizowanym terytorium. Koszty krańcowe netto powinny odnosić się do podmiotów sfery realnej i regulacji gospodarki. Ich katalog przedstawia tabela 1.

\section{Literatura}

Anas A. [2012], Discovering the Efficiency of Urban Sprawl [w:] Urban Economics and Planning, red. N. Brooks, K. Donaghy, G.J. Knaap, Oxford University Press, Oxford. Anas A., Rhee H.J. [2006], Curbing Excess Sprawl with Congestion Tolls and Urban Boundaries, ,Regional Science and Urban Economics”, nr 4, http://dx.doi.org/ 10.1016/j.regsciurbeco.2006.03.003.

Baker K. [2004], Review of Housing Supply, Delivering Stability: Securing Our Future Housing Needs, Final Report - Recommendations, HM Treasury, London.

Beyond Sprawl: New Patterns of Growth to Fit the New California [1995], Bank of America, San Francisco.

Bhatta B. [2010], Analysis of Urban Growth and Sprawl from Remote Sensing Data, Advances in Geographic Information Science, Springer-Verlag, Berlin-Heidelberg.

Bouwman M.E. [2002], Changing Mobility Patterns in a Compact City: Environmental Impacts [w:] Compact Cities and Sustainable Urban Development: A Critical Assessment of Policies and Plans from an International Perspective, red. G. de Roo, D. Miller, Aldershot, United Kingdom, Ashgate.

Breheny M. [1992], Sustainable Development and Urban Form, Pion, London.

Breheny M. [1996], Centrists, Decentrists and Compromisers: Viewson the Future of Urban Form [w:] The Compact City: A Sustainable Urban Form?, red. M. Jenks, E. Burton, K. Williams, E\&FN Spoon, London.

Breheny M. [1997], Urban Compaction: Feasible and Acceptable?, „Cities”, nr 14(4), http://dx.doi.org/10.1016/s0264-2751(97)00005-x.

Breheny M., Gordon I., Archer S. [1998], Building Densities and Sustainable Cities, Project Outline 5, Engineering and Physical Sciences Research Council Sustainable Cities Programme, United Kingdom, Swindon. 
Brueckner J.K. [2000], Urban Sprawl: Diagnosis and Remedies, „International Regional Science Review", nr 23, http://dx.doi.org/10.1177/016001700761012710.

Burchell R.W., Lowenstein G., Dolphin W.R., Galley C.C., Downs A., Seskin S., Still K.G., Moore T. [2002], The Costs of Sprawl. TCRP Report 74, National Academy Press, Washington D.C.

Burton E. [2000], The Compact City: Just or Just Compact? A Preliminary Analysis, „Urban Studies”, vol. 37(11), http://dx.doi.org/10.1080/00420980050162184.

Calthorpe P. [1993], The Next American Metropolis: Ecology, Community and the American Dream, Princeton Architectural Press, New York.

Cervero R. [2001], Efficient Urbanization: Economic Performance and the Shape of the Metropolis, „Urban Studies”, vol. 38(10), http://dx.doi.org/10.1080/ 00420980120084804.

Cheshire P., Sheppard S. [2002], The Welfare Economics of Land Use Planning, „Journal of Urban Economics", vol. 52(2), http://dx.doi.org/10.1016/s0094-1190(02)00003-7.

Ciccone A., Hall R.E. [1996], Productivity and the Density of Economic Activity, „American Economic Review", vol. 86(1).

Compact City Policies: A Comparative Assessment [2012], OECD Green Growth Studies, OECD Publishing, Paris.

Costs of Sprawl: 2000, TCRP Report No. 74 [2002], Transportation Research Board and National Research Council, National Academies Press, Washington D.C.

Costs of Sprawl: Environmental and Economic Costs of Alternative Residential Development Patterns at the Urban Fringe [1974], Real Estate Research Corporation, U.S. Government Printing Office, Washington D.C.

Daneshopur A., Shakibamanesh A. [2011], Compact City: Dose It Create an Obligatory Context for Urban Sustainability?, „International Journal of Architectural Engineering \& Urban Planning", vol. 21, nr 1.

Downs A. [1994], New Visions for Metropolitan America, The Brookings Institution, Washington D.C.

Elkin T., McLaren D., Hillman M. [1991], Reviving the City: Towards Sustainable Urban Development, Friends of the Earth, London.

Ewing R. [1997], Is Los Angeles-Style Sprawl Desirable?, „Journal of the American Planning Association", vol. 63(1), http://dx.doi.org/10.1080/01944369708975728.

Fulton W., Pendall R., Nguyen M., Harrison A. [2002], Who Sprawls Most? How Growth Patterns Differ Across the U.S., Brookings, Washington D.C.

Future Forms and Design for Sustainable Cities [2005], red. N. Dempsey, M. Jenks, Architectural Press, Oxford.

Gordon P., Richardson H.W. [1997], Are Compact Cities a Desirable Planning Goal?, „Journal of the American Planning Association”, vol. 63(1), http://dx.doi.org/10.1080/ 01944369708975727.

Gordon P., Richardson H.W. [1996], Employment Decentralization in U.S. Metropolitan Areas: Is Los Angeles an Outlier or the Norm?, „Environment and Planning A”, vol. 28, http://dx.doi.org/10.1068/a281727.

Green Paper on the Urban Environment [1990], Commission of the European Communities (CEC), EUR 12902 EN, CEC, Brussels.

Guy S., Marvin S. [2000], Models and Pathways: The Diversity of Sustainable Urban Futures [w:] Achieving Sustainable Urban Form, red. K. Williams, E. Burton, M. Jenks, E\&FN Spoon, London. 
Hall P. [2001], Sustainable Cities or Town Cramming? [w:] Planning for a Sustainable Future, red. A. Layard, S. Davoudi, S. Batty, Spon, London.

Haughton G., Hunter C. [1994], Sustainable Cities, Jessica Kingsley Publishers, London. Heimlich E., Anderson W.D. [2001], Development at the Urban Fringe and Beyond. Impacts on Agriculture and Rural Land. Agricultural Economic Report No. 803, „Economic Research Service”, U.S. Department of Agricultural, Washington D.C.

Jackson K. [1985], The Crabgrass Frontier: The Suburbanization of the United States, Oxford University Press, Oxford.

Jenks M. [2000], Compact Cities: Sustainable Urban Forms for Developing Countries, E\&FN Spon, London.

Jenks M., Burton E., Williams K. [1996], Compact Cities and Sustainability: an Introduction [w:] The Compact City: A Sustainable Urban Form?, red. M. Jenks, E. Burton, K. Williams, E\&FN Spoon, London.

Jones C., Leishman C., MacDonald C., Orr A., Watkins D. [2010], Economic Viability [w:] Dimensions of the Sustainable City, red. M. Jenks, C. Jones, Springer, Oxford.

Litman T. [2004], Understanding Smart Growth Savings, Victoria Transport Policy Institute.

Lucas R.E., Rossi-Hansberg E. [2002], On the Internal Structure of Cities, „Econometrica", vol. 70(4), Wiley-Blackwell, Cambridge.

McHarg I.L. [1969], Design with Nature. Garden City, Natural History Press, New York.

Mills E.S. [1999], The Brawl Over So-Called Sprawl, „Illinois Real Estate Letter”, Summer.

Morikawa M. [2011], Economies of Density and Productivity in Service Industries: An Analysis of Personal-Service Industries Based on Establishment-Level Data, „The Review of Economics \& Statistics", vol. 93(1), http://dx.doi.org/10.1162/rest_a_00065.

Mumford L. [1961], The City in History: Its Origins, its Transformations, and its Prospects, Harcourt Brace, New York.

Neuman M. [2005], The Compact City Fallacy, „Journal of Planning Education and Research (JPER)", vol. 25(1), http://dx.doi.org/10.1177/0739456x04270466.

Newman P., Kenworthy J. [1989], Cities and Automobile Dependence: An International Sourcebook, Gower, England.

O’Neil D. [2000], The Smart Growth Tool Kit. Community Profiles and Case Studies to Advance Smart Growth Practices, Urban Land Institute, Washington D.C.

Perrsky J., Wiewel J. [2012], Urban Decentralization, Suburbanization, and Sprawl: an Equity Perspective [w:] Urban Economics and Planning, red. N. Brooks, K. Donaghy, G.J. Knaap, Oxford University Press, New York.

Porter D. [2002], Making Smart Growth Work, Urban Land Institute, Washington D.C.

Prud'homme R., Lee C.W. [1999], Size, Sprawl, Speed and Efficiency of Cities, „Urban Studies", vol. 36(11), http://dx.doi.org/10.1080/0042098992638.

A Study on Regional Infrastructure Management in a De-populating Region, PRI Report No. 86 [2009], Policy Research Institute of Ministry of Land, Infrastructure, Transport and Tourism of Japan, Japan.

Tabuchi T. [1986], Urban Aglomeration, Capital Augmenting Technology, and Labor Market Equilibrium, „Journal of Urban Economics”, vol. 20(2), http://dx.doi.org/ 10.1016/0094-1190(86)90008-2.

Thomas L., Cousins W. [2000], The Compact City: A Successful, Desirable and Achievable Urban Form? [w:] Achieving Sustainable Urban Form, red. K. Williams, E. Burton, M. Jenks, E\&FN Spoon, London. 
Towards a Green Economy: Pathways to Sustainable Development and Poverty Eradication: a Synthesis for Policy Makers [2011], UNEP, www.unep.org/greeneconomy (dostęp: 17.10.2013).

Troy P.N. [1992], The Evolution of Government Housing Policy: The Case of New South Wales 1901-41, „Housing Studies”, vol. 7(3), http://dx.doi.org/10.1080/ 02673039208720737.

Wassmer R.W. [2002], An Economic Perspective on Urban Sprawl: With an Application to the American West and a Test of the Efficacy of Urban Growth Boundaries, California State University, Sacramento.

Williams K. [1999], Urban Intensification Policies in England: Problems and Contradictions, „Land Use Policy”, vol. 16(3), http://dx.doi.org/10.1016/s0264-8377(99)00010-1.

\section{The Economic Consequences of Urban Decentralisation and Centralisation in the Light of Foreign Literature}

The paper looks at theory covered in the foreign literature in English on the economic costs and benefits of urban centralisation and decentralisation. A definitional approach to these two concepts is presented, as is the methodological basis for assessing their economic efficiency. The economic costs and benefits of decentralisation processes and the implementation of centralisation are catalogued. The concepts of urban sprawl and the compact city were used as examples of the determination of the costs and benefits.

Keywords: urban centralisation, urban decentralisation, urban sprawl, the compact city, economic costs, economic benefits. 